\title{
Identifying Strategic Development Objectives for African Countries Using Dominance-Based Rough Set Approach: The Poverty String Theory
}

\author{
Jean-Charles Marin, Bryan Trudel, Kazimierz Zaras \\ Université du Québec en Abitibi-Témiscamingue, Rouyn-Noranda, Canada \\ Email: marj103@uqat.ca, bryan.trudel@uqat.ca, kazimierz.zaras@uqat.ca
}

How to cite this paper: Marin, J.-C., Trudel, B. and Zaras, K. (2018) Identifying Strategic Development Objectives for African Countries Using Dominance-Based Rough Set Approach: The Poverty String Theory. Modern Economy, 9, 1262-1286. https://doi.org/10.4236/me.2018.97082

Received: May 23, 2018

Accepted: July 23, 2018

Published: July 26, 2018

Copyright $\odot 2018$ by authors and Scientific Research Publishing Inc. This work is licensed under the Creative Commons Attribution International License (CC BY 4.0).

http://creativecommons.org/licenses/by/4.0/

\begin{abstract}
The objective of this article is to expose the results of a research using Dominance-based Rough Set Approach (DRSA) to help African countries and international organizations (both non-governmental organizations and governmental organizations), to identify economical, sociological, political and technological strategic objectives for international development. We hope that the results of this research will aid politicians and leaders to prioritize African countries strategic development objectives according to political, economical, sociological and technological (PEST) needs. In this study we use 23 various indicators to classify all the African countries according to the following three different categories: [A] African countries that are doing well according to the selected indicators; [B] African countries that need support to acquire category A status; [C] African countries ranked the lowest and needing special support with regard to the criterion or criteria considered. The three categories are delimited by tertiles obtained from the average ranking of countries. The chosen criteria are measured in order to provide decision rules based on this classification. These decision rules thus focus on the political, economic, sociological and technological needs of countries with respect to improve their development and classification. We strongly believe that by targeting these identified needs, this research will help the development of African countries, target and prioritize International funding, evaluate economic growth and sociological improvements. Our results, from both the correlation matrix and DRSA, clearly demonstrate that top priority should be given to analphabetism, school life and reducing the amount of adolescents pregnancies in order to improve both economically and sociolog-
\end{abstract}


ically. Also, our analysis of the African map belonging to the overall classification results, puts the light over the fact that most countries in category $\mathrm{C}$ are, geographically connected to one another, what we named the "Poverty String". This is the first research of a series of three articles using DRSA in identifying strategic objectives for international development. The second research will discuss the use of DRSA to identify strategic objectives for Bosnia Herzegovina as a potential candidate to the European Union. The third research will use DRSA to help define poverty for all the United Nations countries and propose decision rules for international development.

\section{Keywords}

International Development, African Countries, International Aid, Economic Growth, Strategic Objectives, Rough Set Theory, Dominance-Based Rough Set Approach (DRSA), Selection of Portfolio Projects, Multi-Criteria Analysis, Sustainable Development

\section{Introduction}

This is the first research of a series of three articles using a systematic approach using a combination of statistics and DRSA to help specific territories identifying strategic objectives to improve their development. The first article helps to determine strategic objectives for African countries for international development. The second uses the same methodology to determine strategic objectives for potential candidate countries for the European Union, more precisely with the case of the country of Bosnia-Herzegovina. The third will help identify poverty for all United Nations countries and strategic objectives for sustainable development.

The systematic approach was first presented for a large scale project in the Northern Region of the Province of Quebec (Canada). What we are proposing is a selection of statistical data taken from different census, the World Bank and various indexes. We categorize these variables using different perspectives (Political, Economical, Sociological and Technological) and rank all selected territories (Region, Province or Country) according to these perspectives. When information is missing, we compare states by weighting the average. The last step is to use DRSA to help determine decision rules and conditions for each specific territory. These conditions become strategic objectives in order to improve the territory's development compared to others.

\section{Literature Review}

There are several decision tools to help decision makers and leaders defining strategy and courses of action. Rough set theory, developed by Pawlak [1] [2] and by Pawlak and Slowinski [3], is a mathematical tool that is used to support 
decision-making processes in fields such as medicine, banking, engineering, learning, location selection, pharmacology, finance, market analysis and economics [4]-[11]. It was modified by Greco, Matarazo and Slowinski [12] and renamed the "Dominance-based Rough Set Approach" (DRSA) and later Zaras developed it for mixed data (deterministic, probabilistic and fuzzy) [13]. This research uses DRSA for the purpose of developing sound strategic objectives for all African countries in order to help decision makers, leader, non-governmental organizations, help funds and other international organization or interest groups targeting specific objectives to improve the economic, political, sociological and technological situation in Africa. A total of 114 economic, sociologic, politic and technologic indicators for all 54 African countries were researched. Out of these 114 indicators, a group of DM has selected 23 indicators which were considered most relevant in order to categorize the countries in four different perspectives (PEST).

In this paper, a statistical analysis is presented in Section 2. In this analysis we identify the significant correlations between considered indicators classified per perspectives (PEST). After, in Section 3, we apply DRSA to classify all the African countries with regard to the perspectives (PEST) and present decision rules for each category (countries classified as: A, B and C). Section 4 will propose a strategy map for each individual country, proposing strategic objectives and performance measures to improve and monitor the sustainable development of all African countries.

\subsection{Political, Economic, Sociological and Technological Indicators}

The data of the 23 variables considered in this research were obtained from the World Bank, the United Nations and the International Institute for Strategic Studies [14] [15] [16] during January and March 2018 period. They were divided into four perspectives: political, economic, sociological and technological (PEST) as summarized in Table 1 . Several of these indicators were selected and converted per capita to avoid biases due to the size of the population. It is important to understand that some indexes are scales where a lower score is better and others are more appropriate when the specific subject has a higher score. Table 1 demonstrates each variable divided into perspectives, their definitions and arrows showing if a higher score or lower score is more appropriate.

\subsection{Portrait of Africa}

\subsubsection{Statistics}

Using the various databases presented earlier, we were able to calculate each indicator for the 54 African countries. It is important to mention that we also added 4 indicators for our statistical portrait: \% of type of religion per country (Christianity, Islam, Buddhism, Hinduism, Irreligion, Folk religions and Judaism), oil rents (\% of GDP) and finally percentages of analphabetism male and female. Those variables were not included in the overall classification. 
Table 1. Summary of the PEST indicators considered in this research.

\begin{tabular}{|c|c|c|c|}
\hline $\begin{array}{l}\text { Perspectives and } \\
\text { Measurement }\end{array}$ & Definition & Indicator & $\begin{array}{l}\uparrow=\text { High is better } \\
\downarrow=\text { Low is better }\end{array}$ \\
\hline \multicolumn{4}{|l|}{ Political } \\
\hline $\begin{array}{l}\text { 1.1 Deaths from internal } \\
\text { conflict }\end{array}$ & $\begin{array}{l}\text { Number of battle deaths from internal } \\
\text { conflict between at least one government } \\
\text { armed forces (2017). }\end{array}$ & Scale 1-5 & $\downarrow$ \\
\hline 1.2 Military expenditure & $\begin{array}{l}\text { Cash outlays of central or federal } \\
\text { government to meet the costs of } \\
\text { national armed forces (2017). }\end{array}$ & Scale $1-5$ & $\downarrow$ \\
\hline $\begin{array}{l}1.3 \text { Corruption } \\
\text { perception index }\end{array}$ & $\begin{array}{l}\text { A ranking of countries according to the } \\
\text { extent to which corruption is believed to } \\
\text { exist (2017). }\end{array}$ & Scale $0-100$ & $\uparrow$ \\
\hline $\begin{array}{l}1.4 \text { Global } \\
\text { competitiveness index }\end{array}$ & $\begin{array}{l}\text { Competitiveness along various pillars } \\
\text { (2017). }\end{array}$ & Scale 1-7 & $\uparrow$ \\
\hline $\begin{array}{l}\text { 1.5 Ease of doing } \\
\text { business index }\end{array}$ & Ease of doing business index (2017). & $\begin{array}{l}\text { Ranking of } \\
\text { world country }\end{array}$ & $\downarrow$ \\
\hline $\begin{array}{l}\text { 1.6 Women in } \\
\text { government }\end{array}$ & $\begin{array}{l}\text { Proportion of seats held by women in } \\
\text { national parliaments (2017). }\end{array}$ & $\%$ & $\uparrow$ \\
\hline \multicolumn{4}{|l|}{ Economic } \\
\hline 2.1 GNP per capita & $\begin{array}{c}\text { Gross National Product } \\
\text { (US Constant 2016) divided per capita. }\end{array}$ & $\$$ & $\uparrow$ \\
\hline 2.2 GNI per capita & $\begin{array}{l}\text { Gross National Income per capita Atlas } \\
\text { method (Current US 2017). }\end{array}$ & $\$$ & $\uparrow$ \\
\hline 2.3 Broad money & Broad money (\% of GNP 2017). & $\%$ & $\uparrow$ \\
\hline 2.4 Unemployment & $\begin{array}{l}\text { Unemployment, total } \\
\text { (\% of labor force 2017). }\end{array}$ & $\%$ & $\downarrow$ \\
\hline 2.5 Exports of G \& S & $\begin{array}{l}\text { Exports of goods and services } \\
\text { (\% of GNP 2017). }\end{array}$ & $\%$ & $\uparrow$ \\
\hline \multicolumn{4}{|l|}{ Sociological } \\
\hline $\begin{array}{l}\text { 3.1 Life expectancy, } \\
\text { female }\end{array}$ & $\begin{array}{l}\text { Life expectancy at birth, female } \\
\text { (years 2017). }\end{array}$ & $\begin{array}{l}\text { Number of } \\
\text { years }\end{array}$ & $\uparrow$ \\
\hline 3.2 Life expectancy, male & $\begin{array}{l}\text { Life expectancy at birth, male } \\
\text { (years 2017). }\end{array}$ & $\begin{array}{l}\text { Number of } \\
\text { years }\end{array}$ & $\uparrow$ \\
\hline 3.3 Analphabetism & Percentage of analphabetism (2015). & $\%$ & $\downarrow$ \\
\hline 3.4 School life & School life expectancy (2017). & $\begin{array}{l}\text { Number of } \\
\text { years }\end{array}$ & $\uparrow$ \\
\hline 3.5 Urban population & Percentage of urban population (2017). & $\%$ & $\uparrow$ \\
\hline 3.6 Adolescent fertility & $\begin{array}{l}\text { Number of births per } 1000 \text { women ages } \\
\qquad 15-19(2017)\end{array}$ & Number & $\downarrow$ \\
\hline 3.7 Homicides & $\begin{array}{l}\text { Intentional homicide refers to death } \\
\text { deliberately inflicted on a person by } \\
\text { another person (2017). }\end{array}$ & Scale 1-5 & $\downarrow$ \\
\hline \multicolumn{4}{|l|}{ Technological } \\
\hline 4.1 Academic papers & $\begin{array}{l}\text { Number of scientific published papers per } \\
1 \mathrm{M} \text { population }(2017) .\end{array}$ & Number & $\uparrow$ \\
\hline
\end{tabular}




\begin{tabular}{lcl} 
Continued & & \\
\hline 4.2 Internet & $\begin{array}{c}\text { Fixed broadband internet subscriptions } \\
\text { per 100 people (2017). }\end{array}$ & Number \\
4.3 Fixed telephones & $\begin{array}{c}\text { Fixed telephone subscription per 100 } \\
\text { people (2017). }\end{array}$ & Number \\
& $\begin{array}{c}\text { (2017). } \\
\text { 4.4 Secure internet }\end{array}$ & $\uparrow$ \\
& $\begin{array}{c}\text { Secure internet servers per million people } \\
\text { 4.5 Mobile phones }\end{array}$ & Number \\
& $\begin{array}{c}\text { Mobile cellular subscription per 100 } \\
\text { people (2017). }\end{array}$ & Number \\
\hline
\end{tabular}

Correlation is defined as a measure of the linear relationship between variables [17]. Researching the possibility of relationship between variables will help determine the relationships between the various perspectives (PEST). Since we do only want to check for relationship, and not to invest in understanding the behavior of a variable, we limited our research to correlation, instead of regression analysis.

All correlations presented in this research are significant at the 0.01 level (2-tailed). The correlation matrix is presented in Appendix B.

\subsubsection{Relationship between the Various Indicators}

Testing for significant relationship between two indicators according to:

Null Hypothesis 0: There is no relation between the two indicators.

Alternative Hypothesis 1: There is relation between the two indicators.

Then, after reviewing the data, we reject or not the null hypothesis 0 .

\subsubsection{Relationship between the Political Indicators and Other Variables}

Table 2 is a summary of all the correlations for the Political indicators. Using the correlation matrix, it is plausible that:

1) Military expenditures is positively correlated with the number of fixed telephones;

2) The corruption perception index is positively correlated to the global competitiveness index, GNI per capita, school life (in years), internet subscriptions, secure internet and mobile phones subscriptions. It is negatively correlated to the ease of doing business index;

3) The global competitiveness index is negatively correlated to the ease of doing business index, to all analphabetism variables and adolescent fertility. It is positively correlated to the corruption index, GNP per capita, GNI per capita, broad money, life expectancy for both women and men and all technological indicators except fixed phones;

4) The ease of doing business is negatively correlated to the corruption perception index, global competitiveness, GNI per capita, life expectancy for both females and males, school life in years and all technological indicators. It is positively correlated to analphabetism;

5) The number of women with seats in government has no correlation. 
Table 2. Political perspective correlations.

\begin{tabular}{|c|c|c|c|c|}
\hline $\begin{array}{l}\text { Political } \\
\text { Perspective }\end{array}$ & Other Political & Economical & Sociological & Technological \\
\hline \multicolumn{5}{|l|}{ Internal Conflict } \\
\hline $\begin{array}{c}\text { Military } \\
\text { expenditures }\end{array}$ & & & & +Fixed Telephones \\
\hline $\begin{array}{c}\text { Corruption } \\
\text { perception index }\end{array}$ & $\begin{array}{c}\text { +Global } \\
\text { competitiveness } \\
\text { index } \\
\text {-Ease of doing } \\
\text { business index }\end{array}$ & $\begin{array}{l}\text { +GNI per } \\
\text { capita }\end{array}$ & + School life in years & $\begin{array}{c}\text { +Internet } \\
+ \text { Secure internet } \\
+ \text { Mobile phones }\end{array}$ \\
\hline $\begin{array}{c}\text { Global } \\
\text { competitiveness } \\
\text { index }\end{array}$ & $\begin{array}{l}\text {-Ease of doing } \\
\text { business } \\
\text { +Corruption index }\end{array}$ & $\begin{array}{c}\text { +GNP per } \\
\text { capita } \\
\text { +GNI per } \\
\text { capita } \\
\text { +Broad money }\end{array}$ & $\begin{array}{c}\text { +Life expectancy female } \\
\text { +Life expectancy male } \\
\text {-All analphabetism } \\
\text { variables } \\
\text {-Adolescent fertility }\end{array}$ & $\begin{array}{c}\text { +Academic papers } \\
\text { +Internet } \\
\text { +Secure internet } \\
\text { +Mobile phones }\end{array}$ \\
\hline $\begin{array}{l}\text { Ease of doing } \\
\text { business index }\end{array}$ & $\begin{array}{l}\text {-Corruption index } \\
\text {-Global } \\
\text { competitiveness } \\
\text { index }\end{array}$ & $\begin{array}{l}\text {-GNI per } \\
\text { capita }\end{array}$ & $\begin{array}{l}\text {-Life expectancy for } \\
\text { both female and male } \\
\text {-School life in years } \\
\text { +Analphabetism female }\end{array}$ & -All indicators \\
\hline $\begin{array}{l}\text { Women in } \\
\text { government }\end{array}$ & & & & \\
\hline
\end{tabular}

\subsubsection{Relationship between the Economical Perspective and Other Variables}

Table 3 is a summary of all the correlations for the Economical perspective. Using the correlation matrix, it is plausible that:

1) GNP per capita is positively correlated to the GNI per capita, export of goods and services, global competitiveness index, life expectancy for both women and men, school life expectancy, urban population, internet subscriptions, fixed telephones, secure internet and mobile phone subscriptions. GNP per capita is negatively correlated to all the analphabetism variables (women, men and total);

2) GNI per capita is positively correlated to the GNP per capita, broad money, export of goods and services, life expectancy for both women and men, school life expectancy, urban population and all the technological variables. GNI per capita is negatively correlated to ease of doing business, all analphabetism variables and adolescents fertility;

3) Broad money is positively correlated to the global competitiveness index, GNI per capita, life expectancy for both women and men, urban population, academic papers per capita, internet subscriptions and fixed telephones. Broad money is negatively correlated to adolescent fertility;

4) Unemployment is positively correlated to homicides, mobile phones subscriptions and negatively correlated to analphabetism for women;

5) Exports of goods and services are positively correlated to GNP, GNI, school life expectancy, urban population and mobile phones subscriptions. 
Table 3. Economical perspective correlations.

\begin{tabular}{|c|c|c|c|c|}
\hline $\begin{array}{l}\text { Economical } \\
\text { Perspective }\end{array}$ & Political & $\begin{array}{c}\text { Other } \\
\text { Economical }\end{array}$ & Sociological & Technological \\
\hline GNP per capita & $\begin{array}{c}\text { +Global } \\
\text { competitiveness } \\
\text { index }\end{array}$ & $\begin{array}{l}\text { +GNI per capita } \\
+ \text { Export of goods } \\
\text { and services }\end{array}$ & $\begin{array}{l}\text { +Life expectancy for } \\
\text { both women and men } \\
\text {-All analphabetism } \\
\text { variables } \\
\text { +School life } \\
\text { expectancy } \\
\text { +Urban population }\end{array}$ & $\begin{array}{c}\text { +Internet } \\
\text { +Fixed telephones } \\
+ \text { Secure internet } \\
\text { +Mobile phones }\end{array}$ \\
\hline GNI per capita & $\begin{array}{c}\text { +Corruption } \\
\text { perception index } \\
\text { +Global } \\
\text { competitiveness } \\
\text { index } \\
\text {-Ease of doing } \\
\text { business index }\end{array}$ & $\begin{array}{l}\text { +GNP per capita } \\
+ \text { Broad money } \\
+ \text { Export of goods } \\
\text { and services }\end{array}$ & $\begin{array}{l}\text { +Life expectancy for } \\
\text { both women and men } \\
\text {-All Analphabetism } \\
\text { variables } \\
\text { +School life in years } \\
\text { +Urban population } \\
\text {-Adolescent fertility }\end{array}$ & + All indicators \\
\hline Broad Money & $\begin{array}{c}\text { +Global } \\
\text { competitiveness } \\
\text { index }\end{array}$ & +GNI per capita & $\begin{array}{l}\text { +Life expectancy for } \\
\text { both women and men } \\
\text { +Urban population } \\
\text {-Adolescent fertility }\end{array}$ & $\begin{array}{l}\text { +Academic papers } \\
\text { +Internet } \\
\text { +Fixed telephones }\end{array}$ \\
\hline Unemployment & & & $\begin{array}{l}\text {-Analphabetism } \\
\text { women } \\
\text { +Homicides }\end{array}$ & + Mobile phones \\
\hline $\begin{array}{l}\text { Exports of goods } \\
\text { and services }\end{array}$ & & $\begin{array}{l}\text { +GNP per capita } \\
+ \text { GNI per capita }\end{array}$ & $\begin{array}{l}+ \text { School life in years } \\
+ \text { Urban population }\end{array}$ & +Mobile phones \\
\hline
\end{tabular}

\subsubsection{Relationship between the Sociological Perspective and Other Variables}

Table 4 is a summary of all the correlations for the Sociological perspective. Using the correlation matrix, it is plausible that:

1) Life expectancy for women is positively correlated with the global competitiveness index, GNP and GNI per capita, broad money, life expectancy for men, school life in years, urban population, and all technological variables. Life expectancy for women is negatively correlated to ease of doing business index, analphabetism variables and adolescent fertility;

2) Life expectancy for men is positively correlated with the global competitiveness index, GNP and GNI per capita, broad money, life expectancy for women, school life in years, urban population, academic papers per capita, internet subscriptions, fixed telephones and mobile phones. Life expectancy for men is negatively correlated to ease of doing business index, analphabetism for males and total, adolescent fertility and homicides;

3) Analphabetism (total) is positively correlated with adolescent fertility. It is negatively correlated to the global competitiveness index, GNP and GNI per capita, life expectancy for women and men, school life, internet subscriptions and fixed telephones;

4) School life is positively correlated with the corruption perception index, 
Table 4. Sociological perspective correlations.

\begin{tabular}{|c|c|c|c|c|}
\hline $\begin{array}{l}\text { Sociological } \\
\text { Perspective }\end{array}$ & Political & Economical & Other Sociological & Technological \\
\hline $\begin{array}{l}\text { Life expectancy } \\
\text { women }\end{array}$ & $\begin{array}{c}\text { +Global } \\
\text { competitiveness } \\
\text { index } \\
\text {-Ease of doing } \\
\text { business }\end{array}$ & $\begin{array}{c}+ \text { GNP } \\
+ \text { GNI } \\
+ \text { Broad money }\end{array}$ & $\begin{array}{c}\text { +Life expectancy men } \\
+ \text { School life } \\
+ \text { Urban population } \\
\text {-All analphabetism variables } \\
\text {-Adolescent fertility }\end{array}$ & $\begin{array}{l}\text { +All technological } \\
\text { variables }\end{array}$ \\
\hline $\begin{array}{l}\text { Life expectancy } \\
\text { men }\end{array}$ & $\begin{array}{c}\text { +Global } \\
\text { competitiveness } \\
\text { index } \\
\text {-Ease of doing } \\
\text { business }\end{array}$ & $\begin{array}{c}+ \text { GNP } \\
+ \text { GNI } \\
+ \text { Broad money }\end{array}$ & $\begin{array}{c}\text { +Life expectancy women } \\
\text {-Analphabetism for men } \\
\text { and total } \\
\text { +School life } \\
\text { +Urban population } \\
\text {-Adolescent fertility } \\
\text {-Homicides }\end{array}$ & $\begin{array}{l}\text { +Academic papers } \\
\quad+\text { Internet } \\
\text { +Fixed telephones } \\
\text { + Mobile phones }\end{array}$ \\
\hline $\begin{array}{l}\text { Analphabetism } \\
\text { total }\end{array}$ & $\begin{array}{l}\text {-Global } \\
\text { competitiveness } \\
\text { index }\end{array}$ & $\begin{array}{l}-\mathrm{GNP} \\
-\mathrm{GNI}\end{array}$ & $\begin{array}{c}\text { +Adolescent fertility } \\
\text {-Life expectancy for women } \\
\text { and men } \\
\text {-School life }\end{array}$ & $\begin{array}{l}\text {-Internet } \\
\text {-Fixed telephones }\end{array}$ \\
\hline School life & $\begin{array}{c}+ \text { Corruption } \\
\text { perception index }\end{array}$ & $\begin{array}{l}+\mathrm{GNP} \\
+\mathrm{GNI}\end{array}$ & $\begin{array}{l}\text { +Life expectancy for women } \\
\text { and men } \\
\text {-All analphabetism variables } \\
\text {-Adolescent fertility }\end{array}$ & $\begin{array}{l}\text { All technological } \\
\text { variables }\end{array}$ \\
\hline $\begin{array}{c}\text { Urban } \\
\text { population }\end{array}$ & & $\begin{array}{c}+ \text { GNP } \\
+ \text { GNI } \\
+ \text { Broad money } \\
+ \text { Export of G\&S }\end{array}$ & $\begin{array}{c}+ \text { Life expectancy for women } \\
\text { and men } \\
\text {-Analphabetism for men }\end{array}$ & $\begin{array}{l}\text { +Academic papers } \\
\text { +Mobile phones }\end{array}$ \\
\hline $\begin{array}{l}\text { Adolescent } \\
\text { fertility }\end{array}$ & $\begin{array}{l}\text {-Global } \\
\text { competitiveness } \\
\text { index }\end{array}$ & $\begin{array}{c}\text {-GNI } \\
\text {-Broad money }\end{array}$ & $\begin{array}{c}\text { +All analphabetism } \\
\text { variables } \\
\text {-School life } \\
\text {-Life expectancy for women } \\
\text { and men }\end{array}$ & $\begin{array}{l}\text {-Academic papers } \\
\text {-Internet } \\
\text {-Fixed telephones }\end{array}$ \\
\hline Homicides & & +Unemployment & -Life expectancy men & \\
\hline
\end{tabular}

GNP and GNI per capita, exports of goods and services, life expectancy for women and men and all technological variables. School life is negatively correlated to ease of doing business index, all the variables related to analphabetism and adolescent fertility;

5) Urban population is positively correlated with the GNP and GNI per capita, broad money, exports of goods and services, life expectancy for women and men, academic papers per capita and mobile phones. Urban population is negatively correlated to analphabetism for men;

6) Adolescent fertility is positively correlated with the analphabetism variables. It is negatively correlated to the global competitiveness index, GNI per capita, broad money, school life in years, life expectancy for women and men, academic papers per capita, internet subscriptions and fixed telephones;

7) Homicides index is positively correlated with unemployment and negatively correlated to life expectancy for men. 


\subsubsection{Dependency between Technological Perspective and Other Variables}

Table 5 is a summary of all the correlations for the Technological perspective. Using the correlation matrix, it is plausible that:

1) Academic papers per capita is positively correlated to global competitiveness index, GNI, broad money, life expectancy for women and men, school life, urban population, internet, fixed telephones and mobile phones. Academic papers per capita is negatively correlated to the ease of doing business and adolescent fertility;

2) Internet subscriptions is positively correlated to the corruption perception index, global competitiveness index, GNP and GNI per capita, broad money, life expectancy for women and men, school life and all other technological variables. Internet subscriptions is negatively correlated to the ease of doing business, analphabetism variables and adolescents fertility;

3) Fixed telephones is positively correlated to military expenditures, global competitiveness index, GNP and GNI per capita, broad money, life expectancy for women and men, school life and all the technological variables. Fixed telephones is negatively correlated to the ease of doing business, analphabetism variables and adolescent fertility;

4) Secure internet is positively correlated to the corruption perception index,

Table 5. Technological perspective correlations.

\begin{tabular}{|c|c|c|c|c|}
\hline $\begin{array}{c}\text { Technological } \\
\text { Perspective }\end{array}$ & Political & Economical & Sociological & $\begin{array}{c}\text { Other } \\
\text { Technological }\end{array}$ \\
\hline $\begin{array}{l}\text { Academic } \\
\text { papers per } \\
\text { capita }\end{array}$ & $\begin{array}{c}\text { +Global } \\
\text { competitiveness index } \\
\text {-Ease of doing } \\
\text { business }\end{array}$ & $\begin{array}{c}+ \text { GNI } \\
+ \text { Broad money }\end{array}$ & $\begin{array}{c}+ \text { Life expectancy for women } \\
\text { and men } \\
+ \text { School life } \\
+ \text { Urban population } \\
\text {-Adolescent fertility }\end{array}$ & $\begin{array}{l}\text { +Internet } \\
\text { +Fixed } \\
\text { telephones } \\
\text { +Mobile } \\
\text { phones }\end{array}$ \\
\hline $\begin{array}{c}\text { Internet } \\
\text { subscriptions }\end{array}$ & $\begin{array}{c}\text { +Corruption } \\
\text { perception index } \\
+ \text { Global } \\
\text { competitiveness index } \\
\text {-Ease of doing } \\
\text { business }\end{array}$ & $\begin{array}{c}+ \text { GNP } \\
+ \text { GNI } \\
+ \text { Broad money }\end{array}$ & $\begin{array}{l}\text { +Life expectancy for women } \\
\text { and men } \\
\text {-All analphabetism variables } \\
+ \text { School life } \\
\text {-Adolescents fertility }\end{array}$ & $\begin{array}{c}+ \text { All } \\
\text { technological } \\
\text { variables }\end{array}$ \\
\hline $\begin{array}{c}\text { Fixed } \\
\text { telephone }\end{array}$ & $\begin{array}{l}\text { +Military expenditure } \\
\text { +Global } \\
\text { competitiveness index } \\
\text {-Ease of doing } \\
\text { business }\end{array}$ & $\begin{array}{c}+ \text { GNP } \\
+ \text { GNI } \\
+ \text { Broad money }\end{array}$ & $\begin{array}{l}\text { +Life expectancy for women } \\
\text { and men } \\
\text {-All analphabetism variables } \\
+ \text { School life } \\
\text {-Adolescents fertility }\end{array}$ & $\begin{array}{l}+ \text { All } \\
\text { technological } \\
\text { variables }\end{array}$ \\
\hline $\begin{array}{c}\text { Secure } \\
\text { internet }\end{array}$ & $\begin{array}{l}\text { +Corruption } \\
\text { perception index } \\
\text {-Ease of doing } \\
\text { business }\end{array}$ & $\begin{array}{l}+\mathrm{GNP} \\
+\mathrm{GNI}\end{array}$ & $\begin{array}{c}\text { +Life expectancy for women } \\
\text {-Analphabetism for women } \\
+ \text { School life }\end{array}$ & $\begin{array}{l}\text { +Internet } \\
\text { +Fixed } \\
\text { telephones } \\
\text { +Mobile } \\
\text { phones }\end{array}$ \\
\hline $\begin{array}{l}\text { Mobile } \\
\text { phones }\end{array}$ & $\begin{array}{c}\text { +Corruption } \\
\text { perception index } \\
+ \text { Global } \\
\text { competitiveness index } \\
\text {-Ease of doing } \\
\text { business }\end{array}$ & $\begin{array}{c}\text { +GNP } \\
+ \text { GNI } \\
+ \text { Unemployment } \\
+ \text { Exports of G \& S }\end{array}$ & $\begin{array}{l}\text { +Life expectancy for women } \\
\text { and men } \\
\text {-Analphabetism for women } \\
\text { +School life } \\
\text { +Urban population }\end{array}$ & $\begin{array}{l}+ \text { All } \\
\text { technological } \\
\text { variables }\end{array}$ \\
\hline
\end{tabular}


GNP and GNI per capita, life expectancy for women, school life, internet subscriptions, fixed telephones and mobile phones subscriptions. Secure internet is negatively correlated to the ease of doing business, analphabetism for women;

5) Mobile phones subscriptions is positively correlated to the corruption perception index, global competitiveness index, GNP and GNI per capita, unemployment, exports of G \& S, life expectancy for women and men, school life, urban population and all other technological variables. Mobile phones subscriptions is negatively correlated to the ease of doing business and analphabetism for women.

\section{The Dominance-Based Rough Set Approach (DRSA) Applied to Estimate the Strategic Developmental Goals of African Countries}

\subsection{Description}

The following section presents the application of the Dominance-based Rough Set Approach (DRSA) in order to determine the strategic objectives of each African country and improve their overall classification. Our methodology consists of the following steps: First, all the African countries are classified per perspectives in category A, B or C: Category [A] African countries that are doing well according to the selected indicators; [B] African countries that need support to acquire category A status; [C] African countries ranked the lowest and needing special support with regard to the criterion or criteria considered. Table 6 demonstrates the evaluation of the 54 African countries with respect to the four conditional criteria as determined on the basis of each perspectives (PEST) and with respect to the decisional criterion. Second, decision rules are determined for all the variables on a first time, and on a second time individually on each perspective (PEST). Third, each African country could determine and prioritize its strategic objectives with regard to their respective variables and values.

\subsection{Formulation of the Multi-Criteria Problems}

The first issue was the ranking of the 54 countries on the basis of the 23 criteria measured by 23 indicators. Next, the same was done for each perspective on the basis respective criteria. It can be represented using the AXE model, where:

$A$ is a finite set of countries $a_{i}$ for $i=1,2, \ldots, 54$.

$X$ is a finite set of criteria $X_{k}$ for $k=1,2, \ldots, 23$ or $X_{k j}$ for $k_{j}=1,2, \ldots, n j$ for each perspective $j$.

$E$ is the set of evaluations measured by indicators $e_{i k}$ with respect to criterion $X_{k}$ or indicators $e_{i k j}$ with respect to criterion $X_{k j}$ for each perspective $j$.

The ranking of countries was obtain using the weighted average rank method, in which the countries are ranked from the most to the least preferable in terms of each indicator in relation to each criterion. Next, we calculate for each country the weighted average rank in order to obtain the ranking of the countries with respect to a given perspective and overall. (In this study the weights of indicators are assumed equal.) 
Table 6. Overall classification of the 54 African countries according to the four perspectives.

\begin{tabular}{|c|c|c|c|c|c|}
\hline Decision & Countries & Political & Economic & Sociological & Technological \\
\hline $\mathrm{A}$ & Seychelles & A & A & $\mathrm{A}$ & $\mathrm{A}$ \\
\hline A & Mauritius & A & A & A & A \\
\hline A & Tunisia & A & A & A & A \\
\hline A & Cabo Verde & A & A & A & A \\
\hline A & South Africa & A & A & A & A \\
\hline A & Morocco & A & A & A & A \\
\hline A & Botswana & A & A & A & A \\
\hline A & Algeria & B & A & A & $\mathrm{A}$ \\
\hline A & Namibia & A & A & B & A \\
\hline A & Egypt & B & A & A & A \\
\hline A & Ghana & A & A & A & A \\
\hline A & Gabon & B & A & A & A \\
\hline A & Senegal & $\mathrm{A}$ & B & B & A \\
\hline A & Sao Tome and Principe & B & $\mathrm{B}$ & A & B \\
\hline A & Libya & $\mathrm{C}$ & $\mathrm{B}$ & A & A \\
\hline A & Djibouti & B & A & A & B \\
\hline A & Rwanda & A & $\mathrm{C}$ & A & B \\
\hline A & Swaziland & B & A & $\mathrm{C}$ & A \\
\hline B & Kenya & A & B & A & B \\
\hline B & Equatorial Guinea & A & A & B & B \\
\hline B & Benin & B & A & B & B \\
\hline B & Zambia & A & B & B & B \\
\hline B & Cameroon & B & B & A & B \\
\hline B & Zimbabwe & $\mathrm{C}$ & B & B & A \\
\hline B & Togo & B & B & B & B \\
\hline B & Côte d'Ivoire & B & B & $\mathrm{C}$ & A \\
\hline B & Republic of the Congo & $\mathrm{C}$ & A & B & B \\
\hline B & Tanzania & A & B & B & $\mathrm{C}$ \\
\hline B & Lesotho & A & B & $\mathrm{C}$ & B \\
\hline B & Mauritania & C & B & B & B \\
\hline B & Gambia, the & $\mathrm{C}$ & $\mathrm{C}$ & B & $\mathrm{A}$ \\
\hline B & Angola & $\mathrm{C}$ & A & $\mathrm{C}$ & B \\
\hline B & Ethiopia & A & $\mathrm{C}$ & B & B \\
\hline B & Comoros & $\mathrm{C}$ & $\mathrm{C}$ & B & B \\
\hline B & Madagascar & B & B & A & $\mathrm{C}$ \\
\hline
\end{tabular}




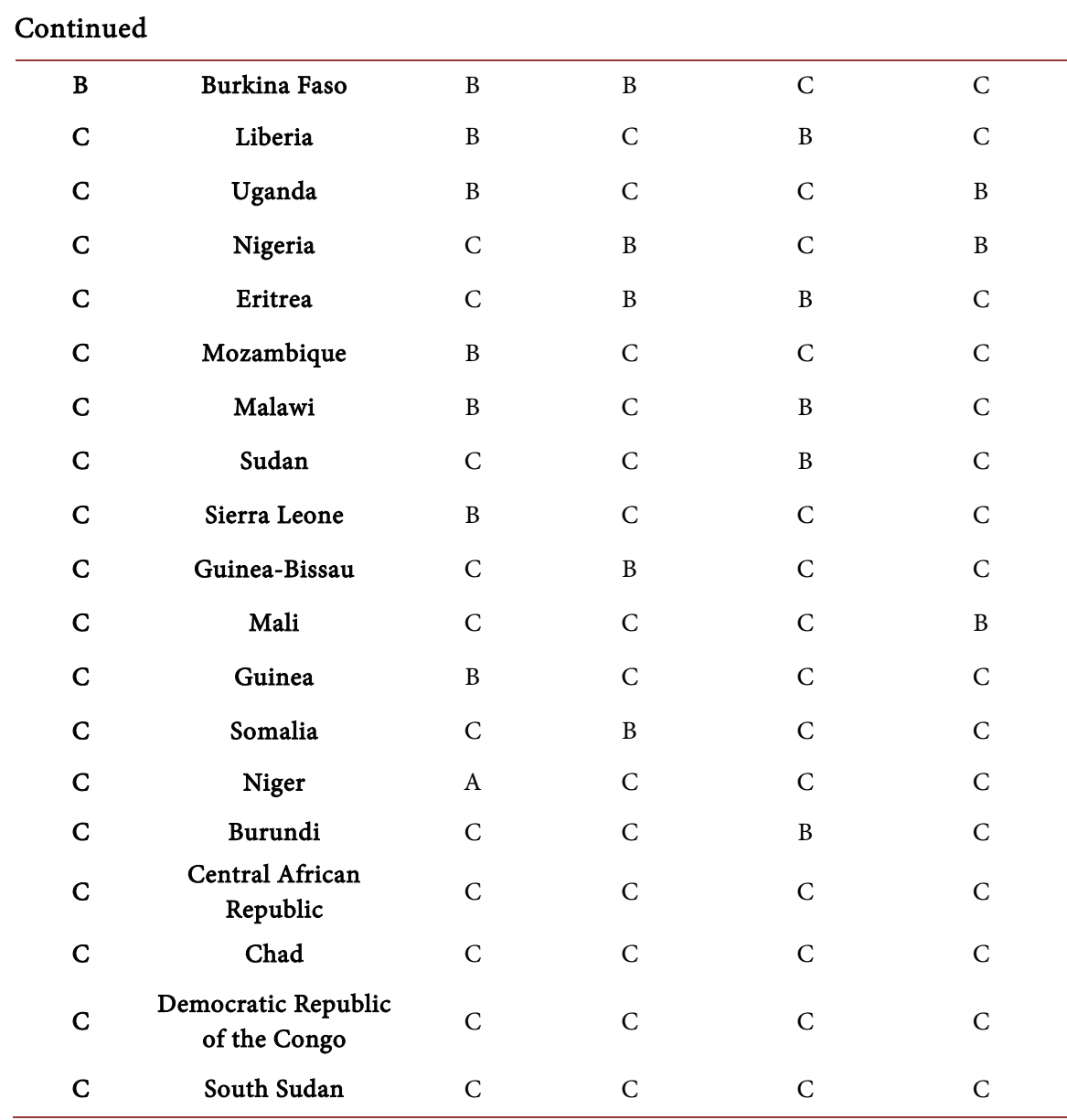

For each perspective $j$, the weighted average of country $i$,

$$
r_{i j}=\sum_{k j} w_{k j} r_{k i j}
$$

The overall weighted average of country $i$,

$$
r_{i}=\sum_{k} w_{k} r_{k i}
$$

where:

$w_{k}$ is the weight of criterion $k$ and $w_{k j}$ for perspective $j$;

$r_{k i}$ is a rank of country $i$ with respect to criterion $k$ and $r_{k i j}$ for perspective $j$.

Then, with the obtained classifications of 54 countries, overall and for each perspective, we have to group into three categories A, B and C, each containing 18 countries. The final overall classification of the 54 African countries according to the four perspectives is presented in Table 6 .

Some decision-makers, after analyzing the position of their country in classification, will want to take actions in the direction of improving their position. To do this, they will need more information that will answer the questions: what criteria are relevant to the given country? What criteria are in conflict? What are the critical values of the criteria? To answer these questions, it was proposed the DRSA explanatory method which allows us with aid of decision rules to find 
critical values of a criterion and determine the placement of a country in one category or another.

\subsection{Geographical Analysis of the Overall Classification Decision Table}

When analysis the overall classification presented in Table 6, most countries listed in category $\mathrm{C}$ seem to be geographically in contact with one another (Sierra Leone, Guinea, Liberia, Mali, Niger, Nigeria, Chad, Sudan, Eritrea, Central African Republic, South Sudan, Uganda and Democratic Republic of the Congo). We decided to call this phenomenon as the "Poverty String" since they are all connected to one another. Most North African countries are categorized as A (Egypt, Morocco, Tunisia and Algeria). Finally, countries neighbouring South Africa are mostly categorized as B. A map of Africa with all the classifications ( $A, B$ and $C$ ) is presented in Appendix A.

\subsection{The Decision Rules}

The calculations were performed using 4eMka2 software, developed by the intelligent decision support systems laboratory (IDSS) at the computing science institute of the Poznan University of Technology. Table 7 describes the rules for all the various perspectives combined. Rules presented below have each a minimal relative strength of $20 \%$ and are limited to 3 conditional criteria in order to get the most significant combination.

From rules 1, 2 and 3, we can conclude that if in the country, the value of the GNP per capita is at least equal to 7503.27 or life expectancy of the men is at least equal to 64.34 years or adolescent fertility is at most equal to 21.18 per 1000 then this country is in the class A no matter the other criteria. For others countries which belong to the classes $B$ or $C$ these critical values determine the strategic objectives to reach and to be in the class A.

The same we can say about countries which belong to the class C. Rules 4 and 5 dictate that for those which homicides index is at most equal to 1.85 or fixed telephone subscriptions is at least equal to 1.22 per 100 then the country is in the class B at least.

In the same manner we can obtain strategies for each perspective individually.

Table 7. Decision rules for all perspectives combined.

\begin{tabular}{|c|c|c|c|}
\hline$\#$ & Decision Rules & Condition 1 & Condition 2 \\
\hline 1 & Decision $\geq \mathrm{A}$ & GNP per capita $\geq 7503.27 \$$ & \\
\hline 2 & Decision $\geq \mathrm{A}$ & Life expectancy men $\geq 64.34$ years & \\
\hline 3 & Decision $\geq \mathrm{A}$ & Adolescents fertility $\leq 21.18$ per 1000 & \\
\hline 4 & Decision $\geq \mathrm{B}$ & Fixed telephone sub. $\geq 1.22$ per 100 & \\
\hline 5 & Decision $\geq \mathrm{B}$ & Homicides index $\leq 1.85$ & \\
\hline
\end{tabular}


Decision Rules for Each Perspective (PEST)

Table 8 describes the decision rules for each individual perspective (PEST).

Table 8. Decision rules for each perspective.

\begin{tabular}{|c|c|c|c|c|}
\hline$\#$ & Decision Rules & Condition 1 & Condition 2 & Condition 3 \\
\hline \multicolumn{3}{|c|}{ Political Perspective } & & \\
\hline 1 & Decision $\geq \mathrm{A}$ & Ease of doing bus. $\leq 106$ & & \\
\hline 2 & Decision $\geq \mathrm{A}$ & Military exp. $\geq 1.54$ & $\begin{array}{l}\text { Ease of doing bus. } \\
\quad \leq 144\end{array}$ & $\begin{array}{l}\text { Competitive. } \\
\text { Index } \geq 3.71\end{array}$ \\
\hline 3 & Decision $\geq \mathrm{B}$ & Ease of doing bus. $\leq 140$ & & \\
\hline 4 & Decision $\geq \mathrm{B}$ & Military exp. $\leq 1.31$ & $\begin{array}{c}\text { Women in } \\
\text { gov. } \geq 12.3 \%\end{array}$ & \\
\hline 5 & Decision $\geq \mathrm{B}$ & Military exp. $\leq 1.7$ & $\begin{array}{l}\text { Corruption } \\
\text { Index } \geq 35\end{array}$ & \\
\hline
\end{tabular}

\begin{tabular}{|c|c|c|c|c|}
\hline \multicolumn{3}{|c|}{ Economic Perspective } & & \\
\hline 6 & Decision $\geq \mathrm{A}$ & GNP per cap. $\geq 1579.92 \$$ & & \\
\hline 7 & Decision $\geq \mathrm{B}$ & GNP per cap. $\geq 820 \$$ & & \\
\hline \multicolumn{5}{|c|}{ Sociological Perspective } \\
\hline 8 & Decision $\geq \mathrm{A}$ & $\begin{array}{l}\text { Life exp. Women } \\
\geq 68.71 \text { years }\end{array}$ & & \\
\hline 9 & Decision $\geq \mathrm{A}$ & Homicides $\leq 1.85$ & $\begin{array}{c}\text { Urban population } \\
\geq 35.74 \%\end{array}$ & \\
\hline 10 & Decision $\geq \mathrm{A}$ & Analphabetism $\leq 11.5 \%$ & Homicides $\leq 2.175$ & \\
\hline 11 & Decision $\geq \mathrm{B}$ & $\begin{array}{l}\text { Life exp. men } \\
\geq 59.66 \text { years }\end{array}$ & & \\
\hline 12 & Decision $\geq \mathrm{B}$ & $\begin{array}{l}\text { School life } \\
\geq 12 \text { years }\end{array}$ & $\begin{array}{l}\text { Life exp. men } \geq \\
59.13 \text { years }\end{array}$ & \\
\hline 13 & Decision $\geq \mathrm{B}$ & $\begin{array}{c}\text { Analphabetism } \\
\leq 13.1 \%\end{array}$ & $\begin{array}{c}\text { Life exp. men } \geq \\
58.59 \text { years }\end{array}$ & \\
\hline \multicolumn{5}{|c|}{ Technological Perspective } \\
\hline 14 & Decision $\geq A$ & $\begin{array}{l}\text { Academic papers } \\
\geq 6.63 \text { per million }\end{array}$ & & \\
\hline 15 & Decision $\geq \mathrm{A}$ & $\begin{array}{l}\text { Mobile phones } \\
\geq 122.02 \text { per } 100\end{array}$ & $\begin{array}{c}\text { Internet } \geq 0.31 \text { per } \\
100\end{array}$ & \\
\hline 16 & Decision $\geq \mathrm{A}$ & $\begin{array}{c}\text { Internet } \\
\geq 0.63 \text { per } 100\end{array}$ & $\begin{array}{c}\text { Academicpapers } \geq \\
2.59 \text { per million }\end{array}$ & $\begin{array}{l}\text { Secure Internet } \geq \\
5.19 \text { per million }\end{array}$ \\
\hline 17 & Decision $\geq \mathrm{B}$ & $\begin{array}{l}\text { Academic papers } \\
\geq 3.48 \text { per million }\end{array}$ & & \\
\hline 18 & Decision $\geq \mathrm{B}$ & $\begin{aligned} & \text { Internet } \\
\geq & 0.1 \text { per } 100\end{aligned}$ & $\begin{array}{c}\text { Fixedtelephones } \geq \\
0.46 \text { per } 100\end{array}$ & $\begin{array}{c}\text { Academicpapers } \geq \\
0.18 \text { per million }\end{array}$ \\
\hline 19 & Decision $\geq \mathrm{B}$ & $\begin{array}{l}\text { Mobile phones } \\
\geq 106.57 \text { per } 100\end{array}$ & $\begin{array}{c}\text { Fixedtelephones } \geq \\
1.2 \text { per } 100\end{array}$ & \\
\hline
\end{tabular}


For the political perspective, according to rules 1 and 2, we can conclude that if in the country, the value of ease of doing business is at most equal to 106 or ease of doing business is at most equal 144 and military expenditures is at least equal to 1.54 and competitive index is at least equal to 3.71 then this country is in the class A. For others countries which belong to the classes B and C these critical values determine the strategic objectives to attaint and to be in the class A.

The same we can say about countries which belong to the class C. Rules 3, 4 and 5 dictate that for those which ease of doing business is at most equal to 140 or military expenditures is at most equal to 1.31 and women in governments is at least equal to 12.3 or military expenditures is at most equal to 1.7 and corruption index is at least equal to 35 are strategic objectives which allow countries to be classify in category B at least.

For the economical perspective, according to rule 6, we can conclude that if in the country, the value of GPN per capita is at least equal to $1579.92 \$$ then this country is in the class A. For others countries which belong to the classes B and $\mathrm{C}$ these critical values determine the strategic objectives to attaint and to be in the class A.

The same we can say about countries which belong to the class C. Rule 7 dictates that for those which GPN per capita is at least equal to $820 \$$ is strategic objective which allow to classify this country to the class $B$ at least.

For the sociological perspective, according to rules 8,9 and 10, we can conclude that if in the country, the value of life expectancy women is at least equal to 68.71 years or homicide is at most equal to 1.85 and urban population is at least equal to $35.74 \%$ or analphabetism is at most equal to $11.5 \%$ and homicides is at most equal to 2.175 then this country is in the class $\mathrm{A}$.

The same we can say about countries which belong to the class C. Rules 11, 12 and 13 dictate that for those which life expectancy men is at least equal to 59.66 years or school life is at least equal to 12 years and life expectancy men is at least equal to 59.13 years or analphabetism is at most equal to $13.1 \%$ and life expectancy men is at least equal to 58.59 years are strategic objectives which will allow to classified this country to the class B at least.

For the technological perspective, according to rules 14,15 and 16, we can conclude that if in the country, the value of academic papers is at least equal to 6.63 per million or mobile phones is at least equal to 122.02 per 100 and internet is at least equal to 0.31 per 100 or internet is at least equal to 0.63 per 100 and academic papers is at least equal to 2.59 per million and secure internet is at least equal to 5.19 per million then this country is in the class A.

The same we can say about countries which belong to the class C. Rules 17 to 19 dictate that for those which academic papers is at least equal to 3.48 per million or internet is at least equal to 0.1 per 100 and fixed telephones is at least equal to 0.46 per 100 and academic papers is at least equal to 0.18 per million or mobile phones is at least equal to 106.57 per 100 and fixed telephones is at least 
equal to 1.2 per 100 are strategic objectives which will allow to classified this country to the class B at least.

\section{Strategic Decision-Making}

This section demonstrates how to apply the decision rules for each country in order to develop strategic objectives and performance measures based on the data provided by the decision rules. Each country categorized overall as [C] (African countries ranked the lowest and needing special support with regard to the criterion or criteria considered) are provided with targets based on the decision rules that apply. In order to improve strategically, each country in category $\mathrm{C}$ must be interested in the decision rules listed in category $\mathrm{B}$ (Decision $\geq \mathrm{B}$ ) in the overall evaluation described in Table 7. For countries in category B, they must be interested in the decision rules listed in category A (Decision $\geq \mathrm{A}$ ). Table 9 describes all the strategic objectives and targets for all the countries classified in category C. Table 10 describes all the strategic objectives and targets for all the countries classified in category B. All countries may decide to evaluate each perspective individually and apply the same process to determine more specific strategic objectives in order to improve their socio-economic situation. Appendix $\mathrm{C}$ shows all the strategic objectives for the various perspectives.

Table 9. Strategic objectives for the countries in category C.

\begin{tabular}{|c|c|c|c|c|}
\hline \multirow[t]{3}{*}{ Country } & Decision Rule \#4 & $\begin{array}{c}\text { Decision } \\
\text { Rule \#5 }\end{array}$ & Strategic Objective & $\begin{array}{c}\text { Strategic Objec } \\
\text { tive }\end{array}$ \\
\hline & Fixed telephone & Homicides & Improve fixed telephone & Lower homicide \\
\hline & subscriptions $\geq 1.22$ per & index $\leq 1.85$ & 5 subscriptions per 100 by: & Index by: \\
\hline Liberia & 0.17 & 2.3 & 1.05 & 0.45 \\
\hline Uganda & 0.89 & 4.18 & 0.33 & 2.33 \\
\hline Nigeria & 0.08 & 4.01 & 1.14 & 2.16 \\
\hline Erythrea & 0.95 & 3.925 & 0.27 & 2.075 \\
\hline Mozambique & 0.3 & 2.4 & 0.92 & 0.55 \\
\hline Malawi & 0.06 & 1.9 & 1.16 & 0.05 \\
\hline Sudan & 0.34 & 3.125 & 0.88 & 1.275 \\
\hline Sierra Leone & 0.26 & 1.95 & 0.96 & 0.1 \\
\hline Guinea-Bissau & 0 & 3.975 & 1.22 & 2.125 \\
\hline Mali & 1.2 & 4.02 & 0.02 & 2.17 \\
\hline Guinea & 0 & 3.675 & 1.22 & 1.825 \\
\hline Somalia & 0.42 & 2.9 & 0.8 & 1.05 \\
\hline Niger & 0.56 & 2.625 & 0.66 & 0.775 \\
\hline Burundi & 0.18 & 2.5 & 1.04 & 0.65 \\
\hline Central Africa & 0.04 & 4.32 & 1.18 & 2.47 \\
\hline Chad & 0.1 & 3.8 & 1.12 & 1.95 \\
\hline $\begin{array}{l}\text { Congo Dem. } \\
\text { Rep. }\end{array}$ & 0 & 4.05 & 1.22 & 2.2 \\
\hline South Sudan & 0 & 4.39 & 1.22 & 2.54 \\
\hline
\end{tabular}


Table 10. Strategic objectives for the countries in category B.

\begin{tabular}{|c|c|c|c|c|c|c|}
\hline Country & $\begin{array}{c}\text { Decision } \\
\text { Rule \#1 }\end{array}$ & $\begin{array}{c}\text { Decision } \\
\text { Rule \#2 }\end{array}$ & $\begin{array}{c}\text { Decision } \\
\text { Rule \#3 }\end{array}$ & $\begin{array}{l}\text { Strategic } \\
\text { Objective }\end{array}$ & $\begin{array}{l}\text { Strategic } \\
\text { Objective }\end{array}$ & $\begin{array}{l}\text { Strategic } \\
\text { Objective }\end{array}$ \\
\hline & $\begin{array}{l}\text { GNP per } \\
\text { capita } \geq \\
7503.27 \$\end{array}$ & $\begin{array}{c}\text { Life } \\
\text { expectancy } \\
\text { men } \geq 64.34 \\
\text { years }\end{array}$ & $\begin{array}{c}\text { Adolescents } \\
\text { fertility } \leq \\
21.18 \text { per } \\
1000\end{array}$ & $\begin{array}{l}\text { Improve GNP } \\
\text { per capita } \\
\text { (USD } \\
\text { constant) by: }\end{array}$ & $\begin{array}{l}\text { Improve Life } \\
\text { expectancy } \\
\text { for men in } \\
\text { years by: }\end{array}$ & $\begin{array}{c}\text { Lower } \\
\text { number of } \\
\text { births per } 1000 \\
\text { adolescents by: }\end{array}$ \\
\hline Kenya & 1143.07 & 64.29 & 90.22 & 6360.2 & 0.05 & 69.04 \\
\hline $\begin{array}{l}\text { Equatorial } \\
\text { Guinea }\end{array}$ & 12278.13 & 56.14 & 107.53 & Maintain & 8.2 & 86.35 \\
\hline Benin & 837.34 & 59.13 & 81.78 & 6665.93 & 5.21 & 60.6 \\
\hline Zambia & 1627.27 & 58.9 & 87.86 & 5876 & 5.44 & 66.68 \\
\hline Cameroon & 1495.44 & 56.4 & 102.36 & 6007.83 & 7.94 & 81.18 \\
\hline Zimbabwe & 917.56 & 58.59 & 108.94 & 6585.71 & 5.75 & 87.76 \\
\hline Togo & 558.12 & 59.15 & 92.06 & 6945.15 & 5.19 & 70.88 \\
\hline Cóte d'Ivoire & 1552.77 & 51.63 & 135.63 & 5950.5 & 12.71 & 114.45 \\
\hline Congo Rep. & 2798.07 & 62.52 & 116.12 & 4705.2 & 1.82 & 94.94 \\
\hline Tanzania & 866.95 & 63.08 & 117.72 & 6636.32 & 1.26 & 96.54 \\
\hline Lesotho & 1352.48 & 51.27 & 93.17 & 6150.79 & 13.07 & 71.99 \\
\hline Mauritania & 1296.01 & 61.6 & 77.9 & 6207.26 & 2.74 & 56.72 \\
\hline Gambia, the & 531.92 & 59.66 & 112.46 & 6971.35 & 4.69 & 91.28 \\
\hline Angola & 3582.65 & 58.42 & 161.93 & 3920.62 & 5.92 & 140.75 \\
\hline Ethiopia & 511.19 & 63.2 & 56.61 & 6992.08 & 1.14 & 35.43 \\
\hline Comoros & 768.44 & 61.81 & 67.1 & 6734.83 & 2.53 & 45.92 \\
\hline Madagascar & 416 & 64 & 114.82 & 7087.27 & 0.34 & 93.64 \\
\hline Burkina Faso & 663.91 & 59.19 & 107.15 & 6839.36 & 5.15 & 85.97 \\
\hline
\end{tabular}

\section{Conclusions}

\subsection{Poverty String Phenomenon}

With the help of the statistical data, we classified all the African countries in three categories: A, B and C. This classification was done according to political, economic, sociological and technological indicators. We were able to obtain a decision table for all perspectives combined and for each perspective individually. It is now clear that there is a strong correlation between different indicators and that economical success requires large investments in improving school life and solutions to reduce adolescent fertility level in order to improve both economically and sociologically. Also, we remind the positive correlation between unemployment and homicides, as well for the negative correlation between unemployment and analphabetism for women. Economic indicators and technological indicators are results indicators. Sociological and political indicators are drivers that will greater impact the overall classification of all the African countries. Leaders, politicians, non-governmental agencies, international organiza- 
tions may now target their investments and know precisely where the development is required and by how much it is required to be improved or reduced.

When analyzing the African map in Appendix $\mathbf{A}$ and all the classification results, we can clearly observe that most countries in category $\mathrm{C}$ are, in majority, geographically touching one another. The opposite is the same as wealth seems to be also grouped. Therefore, it seems that both wealth and poverty spread like diseases. Most countries in category $\mathrm{C}$ share borders with one another along the same latitude. This region is also named Sahel. As demonstrated in the analysis, DRSA shows precisely which indicators should be improved, given priority and by how much for each country classified in category C. Both the correlation matrix and DRSA clearly demonstrate that top priority should be given to analphabetism, school life and reducing the amount of adolescents pregnancies. These three sociological indicators seem to affect directly economic indicators such as GDP, GNI and all technological indicators. The results of the DRSA analysis indicates all the African countries in category $\mathrm{C}$ and by how much each of the actual indicators must be improved since they represent their major weaknesses with regard to other countries.

\subsection{Limitations of the Research}

This research did not include environmental statistics for each country or cultural indicators such as religion percentages. Since most countries in category $\mathrm{C}$ are along the same latitude, climate may play an important role and impact poverty.

\subsection{Future Research}

The original data collection included the percentages of all the different religions within each African country. The researchers understand the sensitivity of the topic discussed in this paragraph. The purpose was to integrate religion since it affects greatly the culture of a nation, its history, laws and traditions. Understanding the importance of religion in all aspect of international relations, politics and sociology, we propose that further research, with the help of sociologists, is needed to study the correlations found between the various PEST indicators and the various religion indicators found in all the African countries.

\section{References}

[1] Pawlak, Z. (1982) Rough Set. International Journal of Parallel Programming, 11, 341-356.

[2] Pawlak, Z. (1991) Rough Sets: Theoretical Aspects of Reasoning about Data. Kluwer Academic Publishing, Dordrecht. https://doi.org/10.1007/978-94-011-3534-4

[3] Pawlak, Z. and Slowinski, R. (1994) Rough Set Approach to Multi-Attribute Decision Analysis. European Journal of Operational Research, 72, 443-459. https://doi.org/10.1016/0377-2217(94)90415-4

[4] Pawlak, Z. (2002) Rough Set Theory and Its Applications. Journal of Telecommunications and Information Theory, 3, 7-10. 
[5] Zaras, K., Marin, J.-C. and Boudreau-Trudel, B. (2012) Dominance Rough Set Approach as a Decision-Making Method for the Selection of Sustainable Development Projects. American Journal of Operational Research, 2, 506.

[6] Ho, H., Fann, W., Chiang, H., Nguyen, P., Pham, D., Nguyen, P. and Nagai, M. (2016) Application of Rough Set, GSM and MSM to Analyze Learning Outcome-An Example Introduction to Education. Journal of Intelligent Learning Systems and Applications, 8, 23-38. https://doi.org/10.4236/jilsa.2016.81003

[7] Renaud, J., Thibault, J., Lanouette, R., Kiss, L.N., Zaras, K. and Fonteix, C. (2007) Comparison of Two Multi-Criteria Methods: Net Flow and Rough Set Methods for aid to Decision Making in a High Yield Pulping Process. European Journal of Operational Research, 177, 1418-1432. https://doi.org/10.1016/j.ejor.2005.04.013

[8] Marin, J., Zaras, K. and Boudreau-Trudel, B. (2014) Use of the Dominance-Based Rough Set Approach as a Decision Aid Tool for the Selection of Development Projects in Northern Quebec. Modern Economy, 5, 723-741.

https://doi.org/10.4236/me.2014.57067

[9] Prema S. and Umamaheswari, P. (2016) Multitude Classifier Using Rough Set Jelinek-Mercer Naïve Bayes for Disease Diagnosis. Circuits and Systems, 7, 701-708. https://doi.org/10.4236/cs.2016.76059

[10] Songbian, Z. (2016) Business Intelligence from Customer Review Management Using Rough Set Model. International Journal of Advanced Research, 4, 816-824.

[11] Emam, O., Farhan, M. and Abohany, A. (2017) Faults Repairing Analysis Using Rough Sets after Implementation of Labor Force Redistribution Algorithm: A Case Study in Telecom Egypt. Information Sciences Letter, 6, 39-48.

[12] Greco, S., Matarazzo, B. and Słowiński, R. (2001) Rough Sets Theory for Multi-Criteria Decision Analysis. European Journal of Operational Research, 129, 1-47. https://doi.org/10.1016/S0377-2217(00)00167-3

[13] Zaras, K. (2004) Rough Approximation of a Preference Relation by a Multi-Attribute Stochastic Dominance for Deterministic, Stochastic and Fuzzy Evaluation Problems. European Journal of Operational Research, 159, 196-206. https://doi.org/10.1016/S0377-2217(03)00391-6

[14] World Bank (2018) Indicators. https://data.worldbank.org/indicator

[15] United Nations (2018) UN Data. http://data.un.org/Explorer.aspx?d=UNODC

[16] International Institute for Strategic Studies. https://www.iiss.org

[17] Field, A. (2005) Discovering Statistics Using SPSS. Second Edition, Sage Publications, New Delhi. 
Appendix A

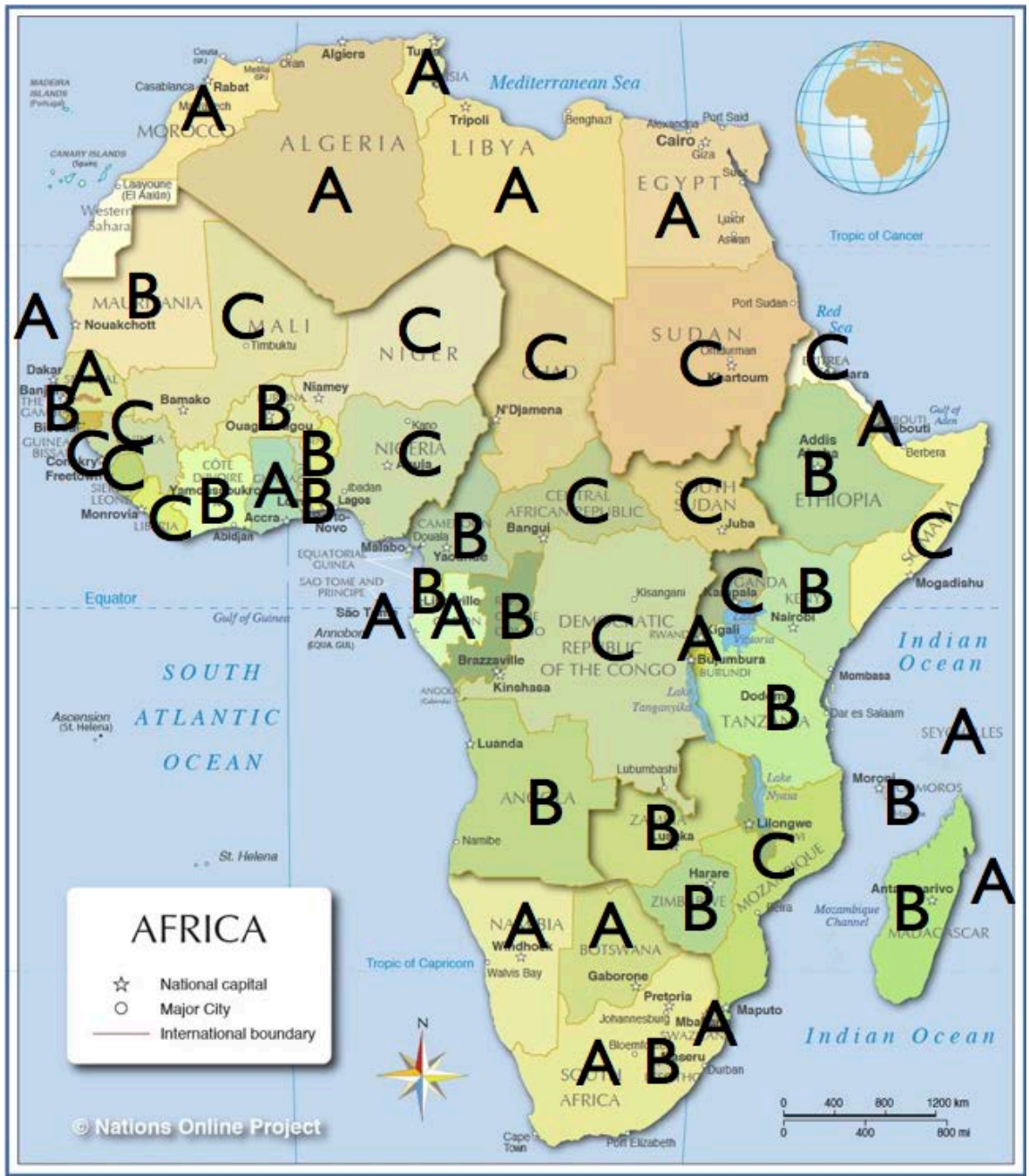


Appendix B

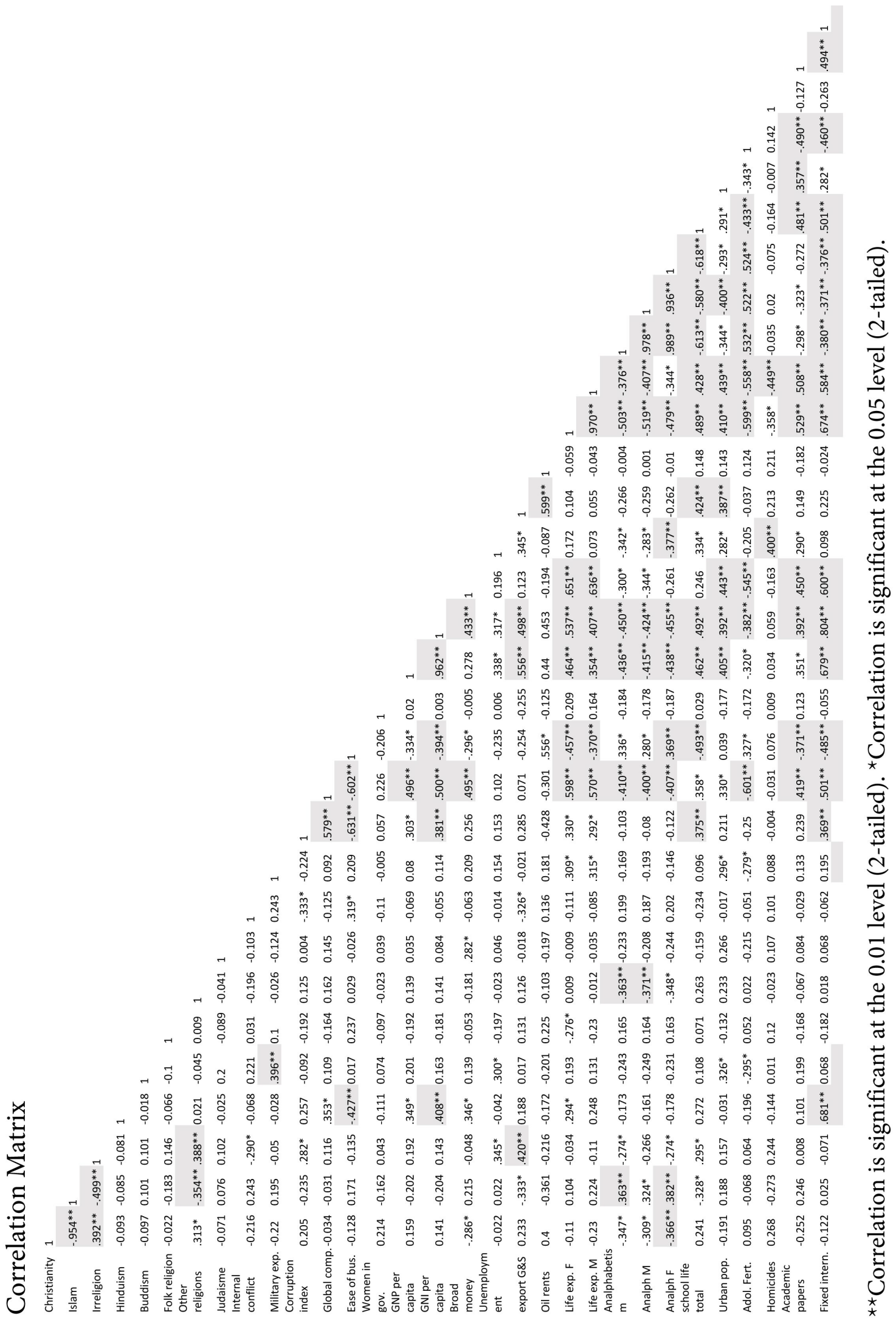




\section{Appendix C}

Strategic Objectives for the four perspectives (PEST)

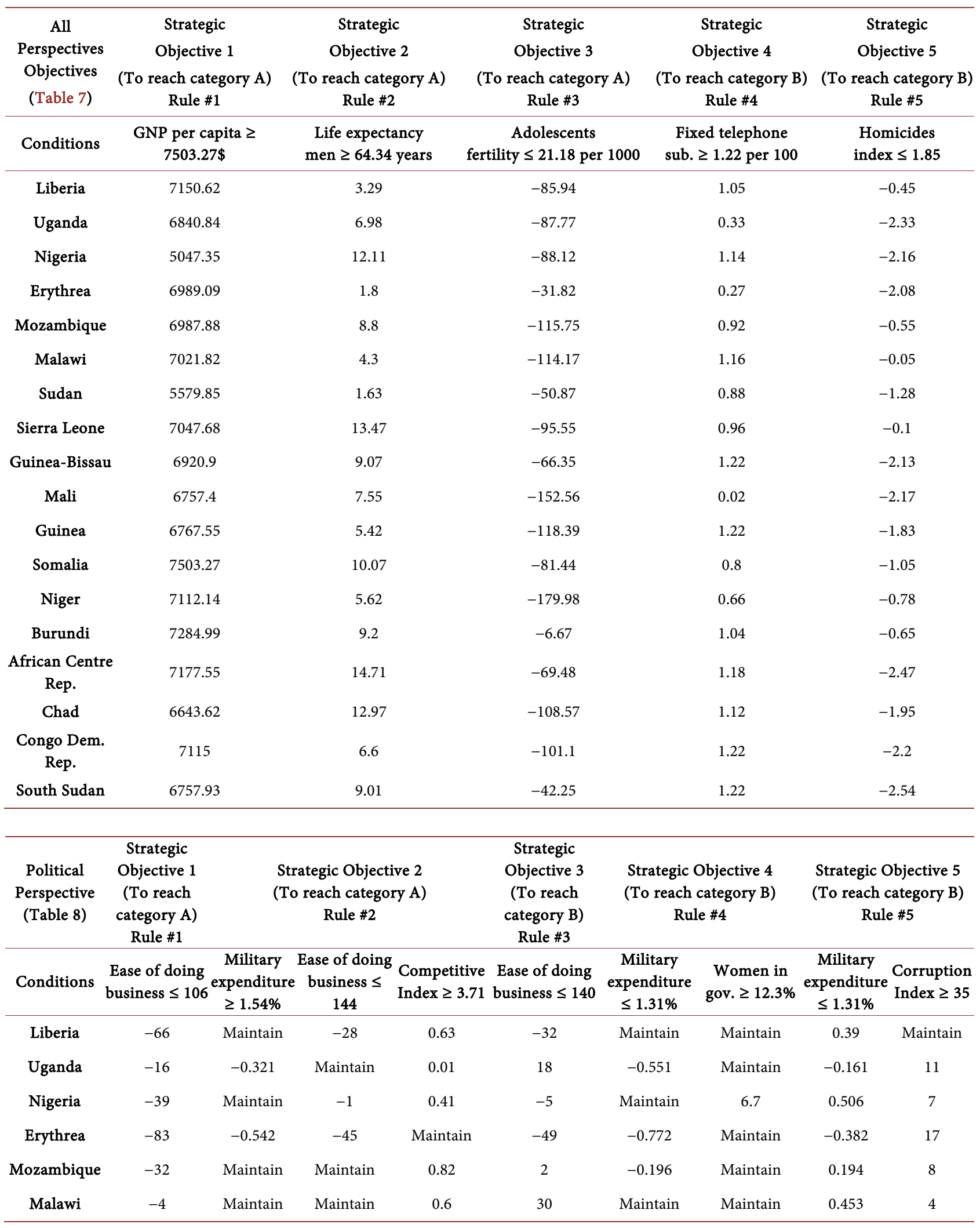


Continued

\begin{tabular}{cccccccccc}
\hline Sudan & -64 & -0.516 & -26 & 3.71 & -30 & -0.746 & Maintain & -0.356 & 21 \\
Sierra Leone & -54 & Maintain & -16 & 0.51 & -20 & Maintain & Maintain & 0.513 & 5 \\
Guinea-Bissau & -70 & -0.593 & -32 & 0.14 & -36 & -0.823 & Maintain & -0.433 & 19 \\
Mali & -37 & -1.416 & Maintain & 0.38 & -3 & -1.646 & 3.5 & -1.256 & 3 \\
Guinea & -47 & Maintain & -9 & 0.24 & -13 & Maintain & Maintain & 0.423 & 8 \\
Somalia & -84 & -0.225 & -46 & 3.71 & -50 & -0.455 & Maintain & -0.065 & 25 \\
Niger & -38 & Maintain & Maintain & 3.71 & -4 & -0.106 & Maintain & 0.284 & 0 \\
Burundi & -58 & -0.423 & -20 & 0.5 & -24 & -0.653 & Maintain & -0.263 & 15 \\
African Centre Rep. & -78 & -0.318 & -40 & 3.71 & -44 & -0.548 & 3.7 & -0.158 & Maintain \\
Chad & -74 & -0.694 & -36 & 0.72 & -40 & -0.924 & Maintain & -0.534 & 15 \\
Congo Dem. Rep. & -76 & -2.421 & -38 & 3.71 & -42 & -2.651 & 3.4 & -2.261 & 15 \\
$\quad$ South Sudan & -81 & -2.088 & -43 & 0.36 & -47 & -2.318 & Maintain & -1.928 & 24 \\
\hline
\end{tabular}

Economical Objectives (Table 8)

\begin{tabular}{|c|c|c|}
\hline Conditions & $\begin{array}{c}\text { Rule \#6 } \\
\text { GNP (US\$) } \geq 1579.92 \$\end{array}$ & $\begin{array}{c}\text { Rule \#7 } \\
\text { GNP }(\text { US } \$) \geq 820 \$\end{array}$ \\
\hline Liberia & 1227.27 & 467.35 \\
\hline Uganda & 917.49 & 157.57 \\
\hline Nigeria & Maintain & Maintain \\
\hline Erythrea & 1065.74 & 305.82 \\
\hline Mozambique & 1064.53 & 304.61 \\
\hline Malawi & 1098.47 & 338.55 \\
\hline Sudan & Maintain & Maintain \\
\hline Sierra Leone & 1124.33 & 364.41 \\
\hline Guinea-Bissau & 997.55 & 237.63 \\
\hline Mali & 834.05 & 74.13 \\
\hline Guinea & 844.2 & 84.28 \\
\hline Somalia & 1579.92 & 820 \\
\hline Niger & 1188.79 & 428.87 \\
\hline Burundi & 1361.64 & 601.72 \\
\hline African Centre Rep. & 1254.2 & 494.28 \\
\hline Chad & 720.27 & Maintain \\
\hline Congo Dem. Rep. & 1191.65 & 431.73 \\
\hline South Sudan & No data & No data \\
\hline
\end{tabular}

(To reach category A refer to rule \#6 and to reach

\section{Strategic Objective 1}

ter




\begin{tabular}{|c|c|c|c|c|c|c|c|c|c|c|c|c|}
\hline \multirow{3}{*}{$\begin{array}{c}\begin{array}{c}\text { Sociological } \\
\text { Objectives } \\
\text { (Table 8) }\end{array} \\
\\
\text { : } \\
\text { : }\end{array}$} & \multirow{2}{*}{$\begin{array}{c}\text { Strategic } \\
\text { Objective 1 } \\
\text { (To reach } \\
\text { category A) } \\
\text { Rule \#8 }\end{array}$} & \multicolumn{11}{|c|}{ Strategic } \\
\hline & & \multicolumn{3}{|c|}{$\begin{array}{c}\text { Strategic Objective } 2 \\
\text { (To reach category A) }\end{array}$} & \multicolumn{2}{|c|}{$\begin{array}{c}\text { Strategic Objective } 3 \\
\text { (To reach category A) } \\
\text { Rule \#10 }\end{array}$} & \multicolumn{3}{|c|}{$\begin{array}{l}\text { Objective } 4 \text { Strategic Objective } 5 \\
\text { (To reach (To reach category B) }\end{array}$} & \multirow{2}{*}{\multicolumn{2}{|c|}{ 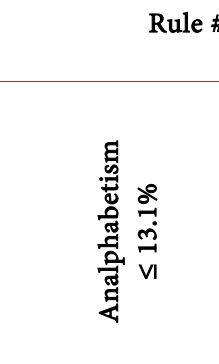 }} & \\
\hline & 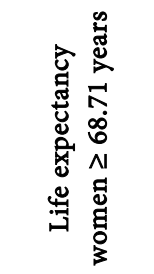 & \multicolumn{2}{|c|}{ 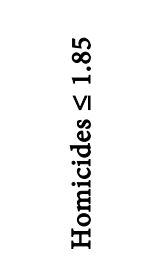 } & 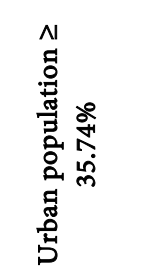 & 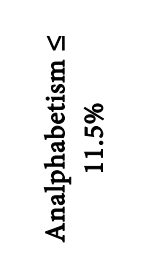 & 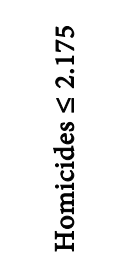 & 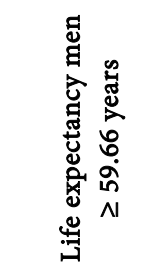 & 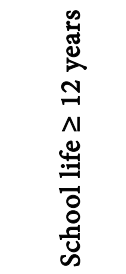 & 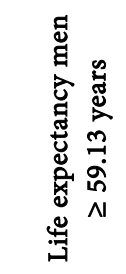 & & & 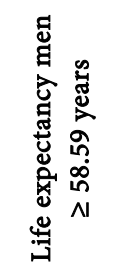 \\
\hline Liberia & 5.75 & \multicolumn{2}{|c|}{-0.45} & Maintain & -40.9 & -0.13 & Maintain & 1 & \multicolumn{2}{|c|}{ Maintain } & -39.3 & Maintain \\
\hline Uganda & 6.94 & \multicolumn{2}{|c|}{-2.33} & 19.3 & -14.7 & -2.01 & 2.301 & 2 & \multicolumn{2}{|l|}{1.77} & -13.1 & 1.23 \\
\hline Nigeria & 14.95 & \multicolumn{2}{|c|}{-2.16} & Maintain & -28.9 & -1.84 & 7.425 & 3 & \multicolumn{2}{|l|}{6.9} & -27.3 & 6.36 \\
\hline Erythrea & 1.9 & \multicolumn{2}{|c|}{-2.08} & 35.74 & -14.7 & -1.75 & Maintain & 7 & \multicolumn{2}{|c|}{ Maintain } & -13.1 & Maintain \\
\hline Mozambique & 8.93 & \multicolumn{2}{|c|}{-0.55} & 3.23 & -29.7 & -0.23 & 4.12 & 2 & 3.59 & & -28.1 & 3.05 \\
\hline Malawi & 3.54 & -0.0 & & 19.29 & -22.5 & Maintain & Maintain & 1 & Maintain & & -20.9 & Maintain \\
\hline Sudan & 2.88 & -1.2 & & 1.73 & -29.9 & -0.95 & Maintain & 5 & Maintain & & -28.3 & Maintain \\
\hline Sierra Leone & 16.72 & -0.1 & & Maintain & -40.1 & Maintain & 8.793 & 12 & 8.26 & & -38.5 & 7.72 \\
\hline Guinea-Bissau & 9.99 & -2.1 & & Maintain & -28.7 & -1.8 & 4.394 & 1 & 3.86 & & -27.1 & 3.32 \\
\hline Mali & 10.55 & -2.1 & & Maintain & -55.4 & -1.85 & 2.874 & 4 & 2.34 & & -53.8 & 1.8 \\
\hline Guinea & 8.8 & -1.8 & & Maintain & -58 & -1.5 & 0.743 & 3 & 0.21 & & -56.4 & Maintain \\
\hline Somalia & 11.15 & -1.0 & & Maintain & Maintain & -0.73 & 5.393 & 5 & 4.86 & & Maintain & 4.32 \\
\hline Niger & 8.01 & -0.7 & & 16.73 & -69.4 & -0.45 & 0.943 & 7 & 0.41 & & -67.8 & Maintain \\
\hline Burundi & 9.62 & -0.6 & & 23.38 & -3 & -0.33 & 4.517 & 1 & 3.99 & & -1.4 & 3.45 \\
\hline $\begin{array}{c}\text { African } \\
\text { Centre Rep. }\end{array}$ & 15.5 & -2.4 & & Maintain & -51.7 & -2.15 & 10.028 & 5 & 9.5 & & -50.1 & 8.96 \\
\hline Chad & 14.92 & -1.9 & & 13.12 & -48.5 & -1.63 & 8.288 & 5 & 7.76 & & -46.9 & 7.22 \\
\hline $\begin{array}{l}\text { Congo Dem. } \\
\text { Rep. }\end{array}$ & 8.03 & -2.2 & & Maintain & -9.2 & -1.88 & 1.918 & 3 & 1.39 & & -7.6 & 0.85 \\
\hline South Sudan & 11.38 & -2.5 & & 16.71 & -56.5 & -2.22 & 4.334 & 12 & 3.8 & & -54.9 & 3.26 \\
\hline $\begin{array}{c}\text { Technological } \\
\text { Objectives } \\
\text { (Table 8) }\end{array}$ & $\begin{array}{c}\text { Strategic } \\
\text { Objective } 1 \\
\text { (To reach } \\
\text { category A) } \\
\text { Rule \#14 }\end{array}$ & $\begin{array}{r}\text { Stra } \\
\text { Objec } \\
\text { (To } \\
\text { categ } \\
\text { Rule }\end{array}$ & $\begin{array}{l}\text { tegic } \\
\text { tive } 2 \\
\text { reach } \\
\text { ory A) } \\
\# 15\end{array}$ & (To & $\begin{array}{r}\text { Strategic } \\
\text { Objective } \\
\text { reach categ } \\
\text { Rule \#16 }\end{array}$ & A) & $\begin{array}{c}\text { Strategic } \\
\text { Objective } 4 \\
\text { (To reach } \\
\text { category B) } \\
\text { Rule \#17 }\end{array}$ & (To re & $\begin{array}{l}\text { Strategic } \\
\text { bjective } 5 \\
\text { ach catego } \\
\text { Rule \#18 }\end{array}$ & y B) & $\begin{array}{r}\text { Str } \\
\text { Obj } \\
(\mathrm{Tc} \\
\text { cate } \\
\text { Ru }\end{array}$ & $\begin{array}{l}\text { tegic } \\
\text { ctive } 6 \\
\text { reach } \\
\text { ory B) } \\
\text { \#19 }\end{array}$ \\
\hline Conditions & 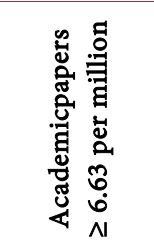 & 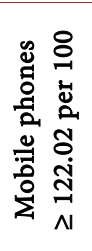 & 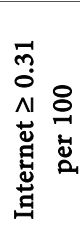 & 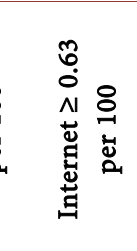 & 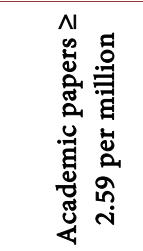 & 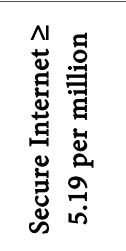 & 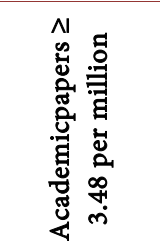 & 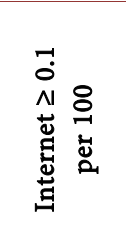 & 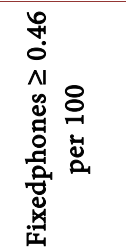 & 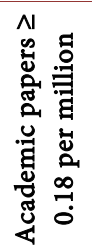 & 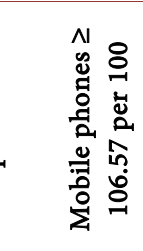 & 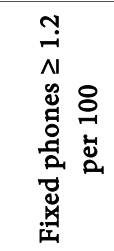 \\
\hline Liberia & 6.09 & 38.92 & 0.14 & 0.46 & 2.05 & 1.51 & 2.94 & Maintain & 0.29 & -0.36 & 23.47 & 1.03 \\
\hline Uganda & 3.64 & 66.95 & 0.05 & 0.37 & Maintain & 2.85 & 0.49 & Maintain & Maintain & -2.81 & 51.5 & 0.31 \\
\hline Nigeria & 0.43 & 40.2 & 0.3 & 0.62 & Maintain & 2.39 & Maintain & 0.085 & 0.38 & -6.02 & 24.75 & 1.12 \\
\hline
\end{tabular}




\section{Continued}

\begin{tabular}{|c|c|c|c|c|c|c|c|c|c|c|c|c|}
\hline Erythrea & no data & 114.73 & 0.3 & 0.62 & no data & no data & no data & 0.09 & Maintain & no data & 99.28 & 0.25 \\
\hline Mozambique & 6.1 & 55.77 & 0.17 & 0.49 & 2.06 & 3 & 2.95 & Maintain & 0.16 & -0.35 & 40.32 & 0.9 \\
\hline Sudan & 3.27 & 53.39 & 0.25 & 0.57 & Maintain & 4.95 & 0.12 & 0.04 & 0.12 & -3.18 & 37.94 & 0.86 \\
\hline Sierra Leone & 6.04 & 24.4 & 0.31 & 0.63 & 2 & 4.51 & 2.89 & 0.1 & 0.2 & -0.41 & 8.95 & 0.94 \\
\hline Guinea-Bissau & 5.09 & 51.76 & 0.27 & 0.59 & 1.05 & 5.19 & 1.94 & 0.061 & 0.46 & -1.36 & 36.31 & 1.2 \\
\hline Mali & 5.7 & 1.71 & 0.28 & 0.6 & 1.66 & 3.47 & 2.55 & 0.065 & Maintain & -0.75 & Maintain & Maintain \\
\hline Guinea & 6.39 & 36.69 & 0.3 & 0.62 & 2.35 & 5.03 & 3.24 & 0.091 & 0.46 & -0.06 & 21.24 & 1.2 \\
\hline Somalia & 6.46 & 63.9 & Maintain & Maintain & 2.42 & 4.98 & 3.31 & Maintain & 0.04 & 0.01 & 48.45 & 0.78 \\
\hline Burundi & 6.28 & 73.98 & 0.27 & 0.59 & 2.24 & 4.52 & 3.13 & 0.065 & 0.28 & -0.17 & 58.53 & 1.02 \\
\hline $\begin{array}{c}\text { African Centre } \\
\text { Rep. }\end{array}$ & 6.01 & 96.53 & 0.29 & 0.61 & 1.97 & 4.32 & 2.86 & 0.08 & 0.42 & -0.44 & 81.08 & 1.16 \\
\hline Chad & 6.51 & 77.54 & 0.24 & 0.56 & 2.47 & 4.91 & 3.36 & 0.025 & 0.36 & 0.06 & 62.09 & 1.1 \\
\hline $\begin{array}{l}\text { Congo Dem. } \\
\text { Rep. }\end{array}$ & 6.58 & 82.54 & 0.31 & 0.63 & 2.54 & 4.81 & 3.43 & 0.099 & 0.46 & 0.13 & 67.09 & 1.2 \\
\hline South Sudan & 6.63 & 100.47 & 0.31 & 0.63 & 2.59 & 4.94 & 3.48 & 0.099 & 0.46 & 0.18 & 85.02 & 1.2 \\
\hline
\end{tabular}

